\title{
FINANCIAL AUTONOMY AS AN AID TO RURAL DEVELOPMENT: A STUDY OF ISOKO NORTH LOCAL GOVERNMENT AREA OF DELTA STATE
}

\author{
Egware Oke Nelson', Akporien Olum Fidelis ${ }^{2}$ and Otuya Sunday ${ }^{3}$ \\ ${ }^{1}$ Department of Accounting, Delta State School of Marine Technology, Burutu, Delta State. \\ ${ }^{2}$ Department of Accounting, Faculty of Business Administration, University of Uyo, Uyo,
} Akwa Ibom State.

${ }^{3}$ Department of Accounting, Edwin Clark University, Kiagbodo, Delta State Email: otuya.sunday@gmail.com

Cite this article:

Egware O.N., Akporien O.F., Otuya S. (2021), Financial Autonomy as an Aid to Rural Development: A Study of Isoko North Local

Government Area of Delta State. African Journal of Accounting and Financial Research 4(3), 63-72. DOI: 10.52589/AJAFR-O9YFJLSV

\section{Manuscript History}

Received: 17 Sept 2021

Accepted: 6 Oct 2021

Published: 14 Nov 2021

Copyright $(92020$ The Author(s). This is an Open Access article distributed under the terms of Creative Commons AttributionNonCommercial-NoDerivatives 4.0 International (CC BY-NC-ND 4.0), which permits anyone to share, use, reproduce and redistribute in any medium, provided the original author and source are credited.
ABSTRACT: Lack of financial autonomy and undue interference by state governments have been identified as some of the impediments to effective administration of local governments in Nigeria. To this end, this study was carried out to examine the effect of financial autonomy on rural development using Isoko North Local Government Area as a case study. The study adopted a survey research design; hence, data were collected through the use of questionnaires administered to the management and staff of selected departments in Isoko North Local Government Council. The findings of the study indicate that financial autonomy will contribute positively to rural development and service delivery in the area of study, and recommends that local governments should be made financially autonomous to promote rural development and enhance better service delivery.

KEYWORDS: Financial Autonomy, Local Government, Rural Development, Staff Productivity. 


\section{INTRODUCTION}

The local government is a subordinate government which derives its existence and power from the law and constitution. Unlike an independent nation-state, the local government is not sovereign. The lack of financial autonomy is one of the problems identified as an impediment to effective administration and management of local governments in Nigeria since the 1976 local government reforms. It has been argued that lack of financial autonomy has plagued local governments in effectively discharging their constitutionally assigned responsibilities.

In recent times, the role of local administration as a vital tool for rapid socio-economic development of both the rural and urban areas have taken a central stage, although without a corresponding access to prerequisite financial resources to meet this expectation. Suffice to say, successive administrations have continued to starve the local councils of needed funds leading to non-availability of funds to cater for the needs of the government at the grassroot level. Nigeria practices a federal system of government with three levels namely the federal, state and local governments. The local government is the nearest form of government to the people especially in the rural area; hence, it is often referred to as the grassroot government. According to Ebiziem and Obi (2015), the federal and state governments are too far to cater for the immediate needs of people at the grass root, hence the birth of the local government (LG) which is constitutionally mandated to take some decisions without the state or federal interference.

Autonomy is the capacity of a system to make a decision about its actions without the involvement of another body or system. Financial autonomy is the ability of a unit or sector to be financially independent without middle aid. Local government financial autonomy is to be proven by the level of fiscal capacity and administrative liberty enjoyed by the local government. Nwabueze (1983) posits that autonomy means that each government enjoys a separate existence and independence from the control of the other governments. Davey (1974) asserts that local autonomy is primarily concerned with the question of responsibilities, resources and discretion conferred on the local authorities. Financial autonomy has the ability to propel local governments to raise and expend financial resources in an efficient and effective manner. The lack of proper financial autonomy to the local government has hampered the performance of local governments in Nigeria, especially in the area of service delivery.

There have been calls from both the academia and policy makers for a full-fledged financial autonomy to the local government so as to engender development and bring dividends of governance closer to the people at the grassroot. However, in spite of the agitation for full financial autonomy to the local government, only a few studies have been able to examine to what extent full autonomy to the local government will impact in terms of rural development and service delivery of the local government administration. This study seeks to fill this gap by exploring the relationship between financial autonomy of the local government and rural development, using Isoko North local Government Area which has been rarely used as a focus in prior studies. 


\section{Conceptual Framework}

Local Council or Government (LG) is an organisation of government created and designed to cater for the needs of the rural people because of the distance to central authority. As a third arm of government, it is saddled with responsibilities of connecting grassroot people to the central government so that people will have a sense of belonging. Local government is a political subdivision of authority which was established by the constitution of the country to control the affairs, and also impose revenue and expend the revenue collected (Mgbachi, 2014).

Local government fiscal autonomy is obtained from the fiscal federalism as practiced in the Nigerian federation. Fiscal federalism itself is to convey powers, functions and resources to levels of government. It is synonymous to the disposition of tax powers and retention of revenue, and criteria is adopted in sharing centrally collected revenue in accordance with the constitutional responsibilities of all tiers of government (Osakwe, 1999). Local government autonomy is defined as the freedom of the local government to recruit and manage its own staff, raise its finances, make bylaws and policies, and discharge its functions as provided by the bylaws without interference from higher authority (Ogunna, 1996). Otinche (2014), Ezeani (2012) and Tumini (2011) explain that the local government has a quality element which includes territory and population, and institutional structure. It is a separate legal entity which can sue and be sued, having a range of powers and functions authorized by delegation from the appropriate central authority with which autonomy is observed.

\section{Theoretical Framework: Efficiency Theory}

This study is anchored on the efficiency theory. This theory is considered most suitable for this study because it is based on the creation of local governments as an efficient change agent of transforming the lives of the local people by providing crucial basic amenities that will aid growth and development in the rural area. Adeyemo (2010) observes that one of the cardinal points for creating local governments is to provide services and it must be applauded by its success in providing services up to a standard measured by national inspectorate. The existence of local governments is also vital in enhancing and drawing the attention of national/central authority to recognize the diversity of tribes, ethnics, languages, cultures and traditional beliefs.

\section{EMPIRICAL REVIEW}

The subject of local government autonomy has been a subject of debate in literature. For instance, Nwankwo, Nwogbo, Atulukwu and Uchenna (2021) examine local government financial autonomy and how local councils can be free from induced interference by the State, especially in the area of operation - state/local government joint account which gives the state government undue advantage over the local government. The study adopted quantitative research design for primary and secondary data, using simple and frequency percentage method, bar chart and chi-square non- parametric techniques to analyse the responses of Ojo Local Government staff in Lagos State. A total population of one hundred and sixty (160) staff of the council was estimated while a sample of 80 questionnaires was administered. Data collected were coded using the chi-square method. The study revealed among others that lack of financial autonomy in Nigeria local government is hindering effective and efficient service delivery at the grassroots. Also, with the use of in-depth interviews, it was observed that undue 
interference of the state government in local affairs, corruption among local government officials, etc. adversely affected the delivery of effective services to the rural dwellers.

Imhanlahimi and Ikeanyibe (2009) examine the topical issue of local government autonomy in Nigeria in relation to the development of the localities. Proceeding from theoretical framework and conceptualizations for clearer understanding, the paper discusses some dominant autonomy issues. These include representative LGs, the size of LGs, revenue, and personnel. The paper found that inadequate handling of virtually all the above issues has posed some challenges to the developmental efforts of the LGs in the localities. Inadequate autonomy has been found to be the independent variable in the challenges. Other challenges include inadequate finances, weak intergovernmental relations, fledgling democracy and grand corruption. These must be adequately tackled for LGs to make a more positive impact in the localities.

Ebiziem and Obioli (2015) appraised the autonomy of local governments as a pre-condition for national development. The study adopted decentralization theory of inter-governmental relations and they found that local governments in Nigeria are not operating in full autonomy. Also, Eme, Izueke and Ngozi (2015) examined the factors responsible for lack of independence and fiscal autonomy by local government in Nigeria; they concluded that lack of independence of the local government is as a result of fiscal autonomy.

Okafor (2010) addressed the statutory financial relations and autonomy of local governments in Nigeria, and the liberty of local governments to collect revenue from its constitutional sources without the interference of higher tiers of government. The result showed that local government autonomy has been negatively affected. Without fiscal autonomy to local governments, the legal, economic and political efforts will not be visible, and there is no gain saying that Nigeria is operating three tiers of government; perhaps, it is a mere assumption.

\section{Research Design, Sources of Data and Population}

The study adopted survey research design in order to capture people's opinion regarding the subject of discussion. The source of data gathering was primarily through the distribution of questionnaires that reflect the objectives of the study. The study was made to cover Isoko North Local Government Area (LGA) of Delta State. The population comprises 80 local government employees randomly drawn from Administration, Accounts, Treasury, Personnel, Works, and Audit departments. Seventy-four correctly filled questionnaires representing 92.5 percent were retrieved and used for analysis.

\section{DATA PRESENTATION AND ANALYSIS}

The demographic distribution of the respondents shows the age range with age bracket 26-35 being the highest with 28.9 percent, and age 56 and above being the lowest with 15.9 percent. It is further observed that the female gender constitutes 52 percent of the sex distribution. Furthermore, the demographic variable shows that 54 percent of the respondents are married with 96.5 percent of the sample being Christians. As regards educational background, 71 percent of the respondents have attended tertiary institutions. In terms of work duration, 34 percent of the respondents have been on the job for 5-9 years. 7.5 percent of the respondents have been on the job for 20 years and above. 


\section{Test of Hypotheses}

This section relates to the testing of hypotheses stated in this study. For the sake of understanding, the hypotheses will be restated before presenting the result analyses. The decision rule is to reject the null hypothesis and accept the alternative if the chi-square $\mathrm{X}^{2}$ calculated is greater than the $\mathrm{X}^{2}$ table value; otherwise, accept the null hypothesis.

Hypothesis One: There is no significant positive association between local government autonomy and rural development.

Table 1: Hypothesis One Table Statistics

\begin{tabular}{|l|l|l|l|l|l|l|}
\hline Response & $\begin{array}{l}\text { Question } \\
\mathbf{0 5}\end{array}$ & $\begin{array}{l}\text { Question } \\
\mathbf{0 6}\end{array}$ & $\mathbf{O E}$ & $\mathbf{E E}$ & (OE-EE) & $\begin{array}{l}(\mathbf{O E}- \\
\text { EE) }\end{array}$ \\
\hline Strongly Agree & 1 & 1 & 2 & 29.6 & -27.6 & 761.76 \\
\hline Agree & 8 & 21 & 29 & 29.6 & -0.6 & 0.36 \\
\hline Undecided & 1 & 0 & 1 & 29.6 & -28.6 & 817.96 \\
\hline Disagree & 29 & 34 & 63 & 29.6 & 33.4 & 1115.56 \\
\hline Strongly Disagree & 35 & 18 & 53 & 29.6 & 23.4 & 547.56 \\
\hline $\begin{array}{l}\text { Total } \\
\mathbf{X}^{2} \text { cal. (OE- } \\
\text { EE) }\end{array}$ & 74 & 148 & 148 & & 3243.2 \\
\hline
\end{tabular}

Key: $\mathrm{X}^{2}=$ chi-square, $\mathrm{OE}=$ Observed Frequency, $\mathrm{EE}=$ Expected Frequency.

Decision: From the table, the calculated $X^{2}$ is 21.96 . The $X^{2}$ table value, given a degree of freedom of 4 and 0.05 significant level, is 9.488 . Since the calculated chi-square value is greater than the table value $(21.96>9.488)$, we therefore have enough evidence to reject the null hypothesis and accept the alternative hypothesis. This implies that there is a significant positive association between local government financial autonomy and rural development in Isoko North Local Government Area of Delta State.

Hypothesis Two: There is no significant positive association between local government financial autonomy and service delivery in Isoko North Local Government Area of Delta State.

Table 2: Hypothesis Two Table Statistics

\begin{tabular}{|l|l|l|l|l|l|l|}
\hline Response & $\begin{array}{l}\text { Question } \\
\mathbf{0 9}\end{array}$ & $\begin{array}{l}\text { Question } \\
\mathbf{1 0}\end{array}$ & OE & EE & (OE-EE) & $\begin{array}{l}(\text { OE- } \\
\text { EE) }\end{array}$ \\
\hline Strongly Agree & 35 & 36 & 71 & 29.6 & 41.4 & 805.16 \\
\hline Agree & 24 & 28 & 52 & 29.6 & 22.4 & 501.76 \\
\hline Undecided & 0 & 1 & 1 & 29.6 & -28.6 & 875.16 \\
\hline Disagree & 11 & 6 & 17 & 29.6 & -12.6 & 859.16 \\
\hline Strongly Disagree & 4 & 3 & 7 & 29.6 & -22.6 & 869.16 \\
\hline $\begin{array}{l}\text { Total } \\
\mathbf{X}^{2} \text { cal. (OE- } \\
\text { EE })^{2} / \mathbf{E E}\end{array}$ & 74 & 74 & & 148 & & 3910.40 \\
\hline
\end{tabular}

Key: $\mathrm{X}^{2}=$ chi-square, $\mathrm{OE}=$ Observed Frequency, $\mathrm{EE}=$ Expected Frequency. 
Decision: From the chi-square table, the critical value is 9.488 using 0.05 level of significance and degree of freedom of 4 . The $X^{2}$ calculated from the above table is 26.42. Since the calculated value is greater than the critical value (24.29>9.488), we therefore reject the null hypothesis and accept the alternate hypothesis, which states that there is a significant positive association between local government financial autonomy and service delivery in Isoko North Local Government Area of Delta State.

\section{Discussion of Findings}

1. The study finds that making local councils financially autonomous will improve on the development of rural areas. This position is supported by prior studies such as Osakede, Ijimakinwa and Adesanya (2016), and Nwankwo, Nwogbo, Atulukwu and Uchenna (2021).

2. The study also finds that local government financial autonomy will contribute to greater service delivery in local government administration. This finding also meets our expectation and is consistent with prior studies such as Fatile and Adejuwon (2014), and Wada and Aminu (2014).

\section{CONCLUSION AND RECOMMENDATIONS}

The aim of the study was to empirically examine the effect of financial autonomy on rural development using Isoko North Local Government Area as a case study. In achieving this aim, the study obtained data through surveys on variables which were believed to have a relationship with financial autonomy and urban development in Isoko North Local Government Area of Delta State. The factors this study focused on are financial autonomy, rural development and service delivery.

The study as part of its findings discovered a significant positive association between financial autonomy of the local government and rural development on one hand, and financial autonomy and service delivery on the other, and concluded that local government financial autonomy is necessary for rural development and service delivery in Isoko North Local Government Area of Delta State.

In line with the findings of this study, it is hereby recommended that there should be full financial autonomy for the local council so as to promote rural development and enhance better service delivery. 


\section{REFERENCES}

Adeyemo, D. O. (2005). Local Government Autonomy in Nigeria: A Historical Perspective" online @http://www.elgf.org.uk/index.cfm/pageid/112/Nigeria.

Afowose, O. (2004). Issues in Local Government administration in Nigeria. Lagos, Lisjohnson Resources Publishers.

Aina, D, A. (2006). State and Local Government in Nigeria. The changing Scene From Native Administration, Divisional Administration to Council Managership and Local Governments in Aborissade, O. and Aransi, I. O. (2008) eds. Pp. 279 - 303 Noth Carolina.Cataoba.

Alao, D, O., Osakede, K. O. \& Owolabi, T. Y. (2015). Challenges of local government administration in Nigeria. Lesson from comparative analysis. International Journal of Development and Economic Sustainability, 3(4), $61-79$.

Chukwuemeka, E., Ugwuanyi, B. I., Okolo, P. \& Onuoha, C. E. (2014). Nigeria Theoretical Imperatives in a Governmental System. African Review An International Multidisciplinary Journal, 8(2) 33., 305 - 334.

Davey, K. J. (1971). Local autonomy and independent revenue. Journal of Public Administration, Spring, 48(45).

Ebiziem, J. E. \& Obi, U. F. (2015). An appraisal of the autonomy of Local government as a pre-condition for National Development.

Eboh, E. \&Diejomaoh, I. (2010). "Local Government in Nigeria: Relevance and Effectiveness in Poverty Reduction and Economic Development". Journal of Economic and Sustainable Development 1, $12-28$.

Eme, O. I.; Izueke, E. \& Ngozi, E. (2015). Local Government and Fiscal Autonomy for Local Government

Ezeani, O. E. (2004). Local Government Administration, Enugu, Nigeria: Zik Chuck Nig: $35-45$.

Imhanlahimi, J.E. \& Ikeanyibe, M. O. (2009). Local government autonomy and development of localities in Nigeria: issues, problems and suggestions. Global Journal Of Social Sciences, 8(2), 13--21

Institute of Chartered Accountant Study Pack on Public Sector Accounting (2014).

Jude, O. (2010). Local government financial autonomy in Nigeria. The State Joint Local Government Account Commonwealth Journal of Local Governance Issue 6: July.

Mgbachi, G.; Ebiziem, J. \& Obi, U. F. (2014). Foundation realities and Challenges of Local government administration in Nigeria, Owerri Ambix Publishers.

Nathaniel, A. U. (2017). Local Governent Autonomy in Nigeria - Myth or reality Retrieved from Nathaniel udoh99@gmail,com

Nwabueze, B. O. (1983). The Presidential Constitution of Nigeria, London: Sweet and Maxwell.

Nwankwo, B.C., Nwogbo, D.C., Atulukwu, A.A. \& Uchenna, M.K. (2021). Local government financial autonomy in Nigeria: A myth or reality. International Journal of Management, Social Sciences, Peace and Conflict Studies (IJMSSPCS), 4(2) 143 157

Ogunna, A. E. C. (1996). A handbook of Local government in Nigeria, Owerri, Versatile Publishers Ltd.

Okoli, F. C. (2009). Theory and Practice of Local government A Nigerian Perspective; Ogui' Bismark Publication. 
Osakede, K.O., Ijimakinwa, S.O. \& Adesanya, T.O. (2016). local government financial autonomy in Nigeria: an empirical analysis. Kuwait Chapter of Arabian Journal of Business and Management Review, 5(11), 24-32

Osakwe, J. O. (1999). "Fiscal Relations among Three Tiers of Government in Nigeria" in Fiscal Federation and Economic Development (NES), University Press.

Otinche, S. I. (2014). Fiscal policy and local government administration in Nigeria: An International Multidisciplinary Journal, Ethiopia, 8(2), 118 - 13744.

Schlachter, B., Coleman, M .\& Anway, H. (2013). Fiscal Policy and Governance Committee key challenges and Strategies for Local Government. University of Pittsburgh Institute of Politics.

Youm, J. \& Feiock, R. (2015). Local governments in the United States cited in http://www.oxfordbibliographiies.com/view/document/ 